\title{
AUTOPERCEPCJA U DZIECI Z CHOROBĄ PRZEWLEKŁĄ
}

Streszczenie: W artykule zostanie podjęta próba syntezy wiedzy teoretycznej oraz uogólnionych rezultatów doniesień empirycznych na temat postrzegania siebie przez dzieci z chorobami przewlekłymi. Należy podkreślić, że proces poznawania siebie, swoich możliwości, ale także ograniczeń w różnych obszarach życia jest długotrwały, niezwykle złożony i wieloczynnikowy, szczególnie jeśli chodzi o dzieci, i musi uwzględniać specyfikę poszczególnych jednostek chorobowych.

Słowa kluczowe: autopercepcja, choroba przewlekła, dziecko z chorobą przewlekłą

\section{Wprowadzenie}

Percepcja, lub inaczej postrzeganie, przyczynia się do organizacji i dokonywania interpretacji wrażeń zmysłowych przede wszystkim po to, aby lepiej rozumieć otaczający świat. Jak czytamy u Edwarda Nęcki i in. (2006, s. 278), jest to proces aktywnej interpretacji danych zmysłowych z wykorzystaniem wskazówek kontekstualnych, nastawienia i wcześniej zdobytej wiedzy. Przyczynia się to w konsekwencji do tego, że człowiek ma świadomość istniejącego wokół niego świata i jego kontekstu.

Percepcja siebie dotyczy złożonych aspektów odnoszących się do postaw człowieka i ujawnianych w oparciu o doświadczenia, wyobraźnię, osobowość oraz wyspecjalizowane strategie działania w określonych sytuacjach. Postrzeganie siebie lub własnego zachowania nie stanowi dla człowieka tylko zbioru doznań odbieranych przez zmysły, które są siatką połączeń nerwowych pozwalających na interpretowanie określonej sytuacji. Ludzie, a szczególnie dzieci, różnią się między sobą sposobem postrzegania otaczającej rzeczywistości. Należy jednak podkreślić, że każdego człowieka wyróżnia właściwy tylko jemu rodzaj przetwarzania informacji oraz charakterystyczny dla niego obraz rzeczywistości (John-Borys 1994, s. 15). Jednostka, wchodząc w różne interakcje społeczne, dokonuje modyfikacji własnego obrazu świata. Wpływ na to ma także środowisko kulturowe 
i materialne. W wyniku tego kształtuje ona własne potrzeby, cele, dążenia, które nie tylko uwzględniają oczekiwania, wymagania szeroko rozumianej przestrzeni społecznej, ale także przyczyniają się do uzyskiwania w tej relacji narastającej autonomiczności. Obraz świata człowieka ma pochodzenie społeczne. Poglądy zależą nie tylko od posiadanej wiedzy, ale też od opinii innych i ich oczekiwań wobec jednostki (Joniec-Bubula 2000, s. 204).

Koncepcja samego siebie oddaje ogół poglądów człowieka na temat własnej osoby. Zawarte w nich treści mają zakodowane w sobie elementy fizyczne, psychiczne, emocjonalne, społeczne oraz określone zachowania, które pozwalają tworzyć opisy postrzeganych cech. Zachowania te, jak czytamy u Piotra Majewicza (2002, s. 48), są w dużym stopniu rezultatem interakcji określonych czynników osobowościowych i sytuacyjnych. Interpretacja zachowań zawsze będzie częściowa, jeśli nie zostaną uwzględnione czynniki osobowościowe. To one w dużej mierze determinują zachowanie jednostki.

W ujawnianym zachowaniu człowieka duży udział ma zazwyczaj subiektywna percepcja jego aktualnej sytuacji. Należy dodać, że w przypadku osób z chorobą ich świadomość siebie samych czy wytworzony w umyśle obraz świata osadzone są w szerszym ujęciu, jakim jest postrzeganie swojego stanu zdrowia - swojej choroby.

Choroba przewlekła jest sytuacją szczególną, która powoduje, że dziecko doświadcza jej w sposób indywidualny, co ujawnia się w postaci podmiotowego odzwierciedlenia. Sukcesywnie gromadzona wiedza jest przekształcana w obraz, koncepcję samego siebie wobec świata i własnej choroby.

\section{Autopercepcja i pojęcia z nią związane - próba analizy znaczeń}

W literaturze przedmiotu spotykamy liczne określenia związane z terminologią i definiowaniem omawianego zagadnienia. Wynika to w dużej mierze z mnogości podejść i ich analiz w różnych ujęciach. Wśród określeń, jakie dotyczą wizerunku własnej osoby lub są z nim zawsze wymieniane, znajdują się pojęcia: ego, self, self-concept (koncepcji siebie, pojęcia siebie), obrazu własnej osoby, obrazu samego siebie, obrazu siebie, obrazu własnego Ja, autoportretu, samowiedzy, samooceny (za: Ostafińska-Molik 2014, s. 62). Należy dodać, że definicja samego siebie jest przedstawiana z dwóch różnych pozycji: (1) akcentuje poznawczy charakter odnoszący się do mechanizmów własnego Ja; pojęcie to uwzględnia wiedzę o sobie samym (pojęcia i system przekonań), która obejmuje zorganizowany system informacji (przekonania na temat siebie samego); (2) akcentuje charakter poznawczy i oceniający własne Ja (człowiek postrzega własną osobę, własne postępowanie, tworzy wyobrażenie o sobie, ocenia siebie w kategoriach pozytywnych lub negatywnych) (Galas, Lewowicki 1991).

Pojęcie własnej osoby (self-concept) jest „zorganizowaną, spójną pojęciowo całością, składająca się ze spostrzeżeń swoich właściwości oraz spostrzeżeń swego 
stosunku do innych ludzi i różnych aspektów życia, łącznie z przypisanymi im właściwościami” (Rogers, za: Mądrzycki 2002, s. 207).

Tadeusz Mądrzycki (2002, s. 209) podaje, że pojęcie własnej osoby obejmuje samoopis i samoocenę, a zatem postrzeganie własnego ciała, określonych właściwości psychicznych oraz relacji z innymi. Samoopis to sądy określające własną osobę, samoocena zaś to sądy oceniające, wartościujące, własne cechy fizyczne, psychiczne i relacje $\mathrm{z}$ innymi.

Inne określenia mające związek $\mathrm{z}$ autopercepcją to: świadomość własnej osoby, która wyraża się poprzez sądy o sobie samym (spostrzeganie siebie - self-perception) (Jarymowicz 1985; Kirenko 2007), samoświadomość (Niebrzydowski 1976). Według Zbigniewa Zaborowskiego samoświadomość może być definiowana jako koncentracja uwagi na własnej osobie albo jako proces kodowania i przetwarzania informacji o sobie, bądź też jako proces uogólniania informacji i dokonywania refleksji na temat siebie samego.

Świadomość siebie samego kształtuje się sukcesywnie w trakcie gromadzenia indywidualnych doświadczeń, jak też opinii usłyszanych od innych. Priorytetowe znaczenie mają te pochodzące od osób znaczących i ważnych w życiu człowieka. W wyniku tych doświadczeń powstaje system poglądów, opinii i sądów mających charakter wartościujący samego siebie (Galas, Lewowicki 1991). Kluczowy jest okres między 11. a 15. rokiem życia; wówczas człowiek uzyskuje pełną świadomość siebie samego. W tym czasie formułuje się samoocena, która zawiera czytelne i wartościujące przez jednostkę cechy osobowości, wpływające na jej zachowanie (Niebrzydowski 1976). Warto podkreślić, że bez względu na wiek stosunek jednostki do siebie zawiera pierwiastek emocjonalny; jednak w okresie dorastania coraz wyraźniej w postrzeganiu siebie zaznacza się wpływ intelektu.

W wyniku rozwoju człowieka, w którym następuje wyodrębnienie własnego Ja, gromadzona jest wiedza dotycząca świata zewnętrznego i własnej osoby. Wiąże się to także z oczekiwaniami, jakie jednostka formułuje wobec siebie. Mogą one przybierać dwojaką formę: niezwerbalizowanych przeświadczeń, które dotyczą możliwości, wyglądu, umiejętności - poczucia własnego Ja oraz świadomych opinii o sobie, formułowanych z użyciem odpowiednich zdań stwierdzających, że daną jed nostkę cechuje to, iż jest... itp. (Ziółkowska 2010, s. 96). Obok kształtowania się Ja świadomego i realnego powstaje Ja idealne, odnoszące się do tego, kim jednostka chciałaby być, jak chciałaby być postrzegana (Kozielecki 1986).

Do głównych źródeł postrzegania siebie należą obserwacje własnej osoby, swoich zachowań, stanów emocjonalnych, wiedza, jaką jednostka tworzy na swój temat, np. w oparciu o zdobywanie informacji o sobie i porównywanie się z innymi. Odnosi się do tego teoria autopercepcji w ujęciu Deryla Bema (1972). Prowadzi to w konsekwencji do tworzenia swoistych schematów wpływających na autopercepcję, określanych przez Hazel Markus (1977) jako poznawcze generalizacje na swój temat. Taki sposób zdobywania informacji pozwala jednostce na oszacowanie swoich kompetencji podczas selekcji, projektowania i wykonywania określonych działań. 


\section{Autopercepcja u dzieci z chorobą przewlekłą}

Rozwój poznawczy odgrywa szczególną rolę wśród wielu czynników, jakie wpływają na proces rozwoju koncepcji siebie i własnej choroby (Pilecka 2002). U dziecka sposób postrzegania swojej choroby zmienia się wraz z wiekiem. Od około 3. do 6. roku życia, kiedy jest ono w preoperacyjnym stadium rozwoju, skupia się głównie na tych objawach choroby, które dostrzega i których doświadcza. Należy podkreślić, że nie ma ono jeszcze wykształconego wyobrażenia na temat przyczyn własnej choroby i jej przebiegu. W tym okresie ujawniają się także trudności ze zrozumieniem sensu leczenia, w szczególności zależności od pewnych działań i czynności medycznych (Vasta i in. 1999). Kolejny etap w rozwoju dziecka to stadium konkretnie operacjonalne, które przypada między 7. a 11. rokiem życia. Dziecko kojarzy i uwzględnia wydarzenia ze swojego życia, w których uczestniczyło; ma także zdolność rozpoznawania pojedynczych faktów, które miały dla niego szczególne znaczenie. W konsekwencji ma możliwość rekonstruowania określonych mechanizmów przyczynowo-skutkowych i ujmowania swojej choroby w kategoriach stanu dynamicznego. Dziecko potrafi zrozumieć doświadczenia z zakresu przeżywania choroby ujawniane u innych osób. Około 12. roku życia (stadium formalno-operacyjne) doskonali się u niego myślenie abstrakcyjne i hipotetyczne. Powoduje to, że swojego stanu nie pojmuje w kategoriach prostej zależności przyczynowo-skutkowej, ale jako coś, na co wpływa wiele czynników i uwarunkowań; zaczyna dostrzegać pewne relacje między swoim stanem fizycznym a procesami psychicznymi. Ujawniane wyobrażenia na temat swojej choroby opisuje, uwzględniając perspektywę czasu - przyszłość bliższą i dalszą (Lohaus 1990).

Możemy wyróżnić kilka czynników determinujących rozwój samego siebie:

1. Doświadczanie bodźców z wnętrza organizmu. Na skutek pojawienia się choroby przewlekłej w pierwszych latach życia dziecka może ulec zakłóceniu rozwój elementarnych składników w zakresie budowania koncepcji samego siebie. Choroba, która towarzyszy dziecku od urodzenia, może być dla niego źródłem przykrych doznań bólowych oraz powodować niemożność zaspokajania podstawowych potrzeb (fizjologicznych, ruchu i aktywności); deprywacja tych potrzeb przyczynia się do wzrostu napięcia, niepokoju, negatywnych emocji. W sytuacji, kiedy choroba pojawia się w późniejszych latach życia, może przyczyniać się do zakłócania nabytych już umiejętności motorycznych i intelektualnych. Dziecko, doświadczając dyskomfortu fizycznego, który jest spowodowany chorobą, nie buduje korzystnych postaw w zakresie koncepcji własnej osoby, szczególnie w odniesieniu do Ja fizycznego (Pilecka 2002, s. 119).

2. Oddziaływanie rodziców. Rodzice w życiu dziecka z chorobą zajmują centralne miejsce; ich obecność łagodzi cierpienie i wzmacnia funkcjonowanie w różnych obszarach. Jak czytamy u Władysławy Pileckiej (2002, s. 119), za działania szczególnie ważne dla prawidłowego rozwoju koncepcji siebie 
można uznać: wartościowanie i ocenianie zachowania dziecka w różnych sytuacjach, nadawanie dziecku pozytywnych określeń, które przyjmuje za swoje i które z czasem stają się określeniami trwałymi w budowaniu koncepcji samego siebie (Ja idealne), dostarczanie wzorów zachowania w określonych sytuacjach, które dziecko naśladuje i tak kształtuje swoje własne cechy, oczekiwanie od dziecka pewnych zachowań w danych sytuacjach.

3. Porównywanie siebie z innymi. Dziecko w wyniku kontaktów z kolegami/ koleżankami zdobywa wiele informacji o sobie; dzieje się to przede wszystkim w efekcie ciągłego porównywania się. Należy zaznaczyć, że zestawianie cech innych z własnymi odnosi się do wyglądu zewnętrznego; dopiero potem dziecko porównuje $\mathrm{z}$ rówieśnikami swoje zdolności intelektualne i pewne cechy charakteru (tamże, s. 119-120).

Do obiektywnych czynników postrzegania siebie i własnej choroby można zaliczyć między innymi: doświadczenia związane z procesem rozwoju własnej choroby, obserwację zachowań i stanów innych osób z chorobą oraz własne relacje społeczne (Pilecka 2011).

Wśród czynników poznawczych, które mają wpływ na kształtowanie się obrazu własnej choroby u dziecka, można wskazać (Ziółkowska 2010, s. 103-106):

1. Świadomość własnej choroby. Odnosi się ona do poczucia bycia chorym, pojawia się w wyniku złego samopoczucia wywołanego szeregiem bodźców płynących z wnętrza ciała.

2. Wiedzę o niej. Jest to proces, w wyniku którego dziecko stopniowo - w miarę rozwoju choroby oraz swoich struktur poznawczych - nabywa wiedzę na temat swoich stanów spowodowanych niepełnosprawnością. Informacji na ten temat dostarczają mu też kontakty z personelem medycznym, innymi dziećmi przebywającymi na oddziale szpitalnym bądź w sanatorium oraz rodzice instruowani przez personel medyczny.

3. Dokonywanie ocen zysków i strat spowodowanych chorobą. Straty bezpośrednie to na przykład ból związany z pewnymi procedurami medycznymi, lęk przed badaniem, unieruchomienie, brak kontaktu $\mathrm{z}$ rodziną i rówieśnikami. Straty odległe w czasie są formą urazów psychicznych - wynikają z bodźców, które dziecko kojarzy z miejscem leczenia i/lub osobami, które sprawują nad nim opiekę w trakcie trwania choroby. Pozytywne doświadczenia wynikające z choroby mogą odnosić się do zmiany codziennych aktywności i obowiązków, w tym także szkolnych.

4. Postrzeganie i ocenę roli własnej i rodziców.

Dziecko, niezależnie od posiadanych zasobów poznawczych, może postrzegać własną chorobę jako coś tajemniczego i niezrozumiałego, a także ujawniać skłonność do uzupełniania braków w wiedzy na temat procesu chorobowego własnymi wyobrażeniami, dokonując nadinterpretacji określonych sytuacji, jak też tworzyć teorie, które niekiedy odbiegają od rzeczywistości. 
Dzieci, które ujawniają negatywny obraz siebie i własnej choroby, mogą swoją przyszłość postrzegać jako niepewną, a także nie mieć motywacji do podejmowania najmniejszego wysiłku, który miałby na celu walkę z chorobą (Ziółkowska 2010).

Przedstawione powyżej ujęcia teoretyczne pokazują, że tworząc koncepcję samego siebie, można ujawniać określone przekonania na temat własnej osoby. Dotyczą one posiadanych kompetencji i dostrzeganych możliwości, prezentowanych zachowań, a także postrzeganych cech i sądów na swój temat. Treść i konstrukcja koncepcji własnej osoby u dziecka ulega zmianie wraz z jego rozwojem. Na etapie wczesnego dzieciństwa powstają opisy koncentrujące się w szczególności na cechach określonego zachowania, na kolejnych etapach rozwoju (średnie dzieciństwo) budowane są obrazy własnej osoby w oparciu o cechy zewnętrzne (wygląd fizyczny) i wyniki podejmowanych działań. Okres dorastania wzbogaca ten obraz o opisy zawierające cechy psychiczne, które wraz z wiekiem zyskują na znaczeniu. Koncepcja samego siebie początkowo przyjmuje u dziecka kształt ogólny i jednorodny. Wraz z rozwojem zmienia się w złożoną i wieloaspektową strukturę. O jej dynamice decydują poziom rozwoju poznawczego oraz ujawniane przez dziecko zachowania adaptacyjne w odniesieniu do jego choroby.

Jak czytamy u Władysławy Pileckiej (2002, s. 118), gwałtowny rozwój koncepcji samego siebie następuje w średnich klasach szkoły podstawowej z uwagi na to, że do formułowania sądów na swój temat wykorzystywane są społeczne porównania. Również w tym czasie występuje u dzieci wzrost świadomości posiadanych zalet i wad w trzech obszarach koncepcji samego siebie: wyglądu zewnętrznego i sprawności motorycznej, akceptacji społecznej oraz osiągnięć szkolnych, co może skutkować bardziej adekwatną do sytuacji samooceną. Dostrzegają one w sobie wiele sprzeczności, które później skutkują powstaniem konfliktów wewnętrznych. Następuje to około 14. roku życia. Radzenie sobie z konfliktami intrapsychicznymi, jak pisze Władysława Pilecka (tamże), jest obok porównań społecznych istotnym elementem rozwoju koncepcji samego siebie. Racjonalne rozwiązywanie wewnętrznych konfliktów wpływa na główne zadania rozwojowe w wieku dorastania. Z jednej strony, przyczynia się do budowania pozytywnej tożsamości jako gwaranta w zakresie podejmowania trafnych decyzji odnoszących się do przyszłości, z drugiej zaś, określa adekwatne różnice pomiędzy Ja realnym i Ja idealnym, pozwalające na ciągłe doskonalenie siebie.

Dziecko kształtuje pozytywne poczucie wartości na skutek eliminowania tych obszarów swojego życia, w których doświadcza porażki. Znamienne jest to, że równocześnie intensyfikuje swoją aktywność w tych dziedzinach, w których odnosi sukces (Harter 1986).

Wpływ na kształtowanie poczucia własnej wartości ma także świadomość kontroli - z uwagi na doświadczenia, jakie osoba gromadzi w wyniku poznawania siebie i najbliższego otoczenia. Poczucie kontroli (locus of control) wynika ze stopnia, w jakim obdarza zaufaniem to, co się wokół niej dzieje, i w jakim jest to uzależnione od prowadzonych przez nią działań. Dzieli się na wewnętrzne 
(przekonania osoby na temat zdarzeń pozytywnych i negatywnych, które są konsekwencją jej zachowania) i zewnętrze (przekonanie o przypadku, biegu losu lub wpływie innych ludzi na nasze życie). Ludzie, u których wewnętrzne poczucie kontroli jest zrównoważone, z łatwością osiągają satysfakcję i zachowują optymizm życiowy z uwagi na to, że poczucie kontroli wewnętrznej znacząco zmniejsza poziom stresu. To w konsekwencji determinuje skuteczne sposoby dawania sobie rady w sytuacjach trudnych. Wewnętrzne umiejscowienie kontroli przyczynia się do tego, że jednostka stosuje strategie zmierzające do rozwiązania danego problemu. Błędne doświadczanie poczucia kontroli może z kolei powodować ujawnianie się trudności adaptacyjnych w danych sytuacjach (Rotter 1966).

Koncepcja świata oddaje ogół doświadczeń jednostki, które odnoszą się do jej szeroko ujmowanego i postrzeganego środowiska. Mogą mieć one formę sądów opisowych (zdobywania wiedzy o świecie), oceniających (ocena świata) oraz normatywnych (formułowanie wyobrażeń na temat tego, jaki świat powinien być). Źródło wiedzy o świecie stanowią zarówno postawy społeczne, jak i aktywność samej jednostki, jej działania i ich skutki (Kozielecki 1986).

Analizując wyniki badań na temat koncepcji świata dzieci i młodzieży - zarówno zdrowych, jak też z różnymi chorobami somatycznymi - można zauważyć, że koncepcje te są podobne pod względem treści i wymiaru emocjonalnego. Różnorodność ujawnianych treści zależy w sposób oczywisty od doświadczeń w różnych obszarach funkcjonowania (Pilecka 2002, 2011).

$\mathrm{W}$ procesie tworzenia koncepcji siebie i świata $\mathrm{u}$ dzieci $\mathrm{z}$ chorobą przewlekłą istotną pozycję zajmuje poznawcza reprezentacja odczuwanych dolegliwości w odniesieniu do konkretnych sytuacji, tak zwany obraz lub koncepcja własnej choroby. Jej istotą jest to, że odzwierciedla wszystkie doświadczenia dziecka, które mają związek z odgrywaniem roli osoby z chorobą. Obejmuje wiedzę na temat choroby, przeżycia i doznania wywołane przez chorobę, jak też określone reakcje i zachowania, które przyczyniają się do dawania sobie rady w tej sytuacji. Dzieci, podobnie jak osoby dorosłe, tworzą koncepcję swojej choroby w oparciu o osobiste przeżycia somatyczne i psychiczne wywołane w trakcie leczenia, opinie usłyszane od rodziny i innych pacjentów, informacje uzyskane od personelu medycznego, jak też samodzielnie wraz z wiekiem czerpiąc coraz więcej wiedzy z literatury oraz mass mediów. Proces powstawania koncepcji własnej choroby jest uzależniony od okresu rozwoju dziecka, w którym pojawiła się choroba. W sytuacji, kiedy choruje ono od urodzenia, jego choroba staje się nieodłączną częścią życia, a doświadczany stan somatyczny jednym z komponentów jego fizycznego Ja. Dziecko potrafi wtedy ocenić własną chorobę w okresie dorastania, kiedy osiąga pewien poziom rozwoju samoświadomości. Natomiast jeśli choroba pojawia się później (po 5. roku życia), to w powstawaniu jej koncepcji możemy u niego wyróżnić dwie fazy. Pierwsza trwa do momentu zachorowania - dziecko tworzy reprezentację poznawczą własnej choroby, jednak nie zajmuje ona centralnego miejsca w całej wiedzy o świecie; w drugiej fazie do dziecka docierają nowe informacje, powodując 
powstawanie ogólnej reprezentacji poznawczej choroby w połączeniu z koncepcją choroby własnej i stając się tym samym centralnym punktem w tworzeniu wiedzy o sobie (Pilecka 2002). Nawet nieznaczące zmiany w samopoczuciu dziecka, jego otoczeniu, relacjach z innymi przyczyniają się do tego, że zaczyna ono dostrzegać wpływ choroby na własne życie.

Problematyka dotycząca kształtowania się koncepcji samego siebie u dzieci i młodzieży z chorobą przewlekłą nie była przedmiotem rozległych porównawczych analiz badawczych. W literaturze przedmiotu spotykamy jednak opinie i refleksje w odniesieniu do prowadzonych badań dzieci z konkretną jednostką chorobową.

Prace Heleny Adamskiej (1981) pokazują, że osoby w wieku 9-15 lat z reumatoidalnym zapaleniem stawów mają poczucie „inności fizycznej”. Pojawiające się zniekształcenia kończyn, ograniczenia w zakresie samodzielności i samowystarczalności kształtują u nich charakterystyczny obraz własnej osoby, potrzeb, oczekiwań oraz hierarchię wartości. Wśród ujawnianych przez nie cech zachowania daje się zauważyć dominację koncentracji na sobie oraz tendencję do wycofywania się z kontaktów z innymi.

Poczucie odmienności fizycznej u dzieci z chorobą przewlekłą potwierdzają badania przeprowadzone wśród dziewcząt z idiopatycznym skrzywieniem kręgosłupa. Uważają one, że nie zasługują na uznanie, a ich cechy obrazu własnej osoby zawierają poczucie słabości fizycznej i małą pewność siebie. Pomimo to badane przyznają, że posiadają cechy akceptowane społecznie (są koleżeńskie, miłe, uczciwe, wesołe, lubiane). W obrazie perspektywicznym wskazują doskonalenie takich cech, jak opanowanie i wytrwałość. Można odnieść wrażenie, że są one niezbędne do osiągnięcia postawionych celów, realizacji własnych marzeń i planów. Wśród cech najbardziej u siebie pożądanych badane wskazały: „zdrowa”, „silna”, „wyprostowana”, „śmiała” (Radecka i in. 1998).

Poczucie własnej inności występuje także w opisach dzieci z niedoborem wzrostu. Swoją odmienność dostrzegają szczególnie te z nich, które oprócz niskiego wzrostu mają widoczne zniekształcenia fizyczne. To są główne predykatory ich negatywnych przeżyć $\mathrm{w}$ relacjach $\mathrm{z}$ innymi. Ujawniana $\mathrm{w}$ tej grupie samoocena jest zaniżona i pomimo że z upływem lat młodzież przyzwyczaja się do swojego wyglądu, to w sytuacji zmiany środowiska ukrywane problemy emocjonalne wzrastają (Mazurowa i in. 1981).

Również dzieci chore na wrzodową chorobę żołądka i dwunastnicy mają poczucie niższości i mniejszej sprawności fizycznej. W swoich działaniach unikają współzawodnictwa $z$ rówieśnikami oraz czują lęk przed podejmowaniem samodzielnych działań. Mimo tego dzieci te ujawniają pilność, pracowitość i duże ambicje. Jednak nie mają poczucia sukcesu czy satysfakcji ze swoich osiągnięć (Sufczyńska-Kotowska i in. 1981).

Niskie poczucie własnej wartości, brak samoakceptacji, świadomość zależności od innych i swojej inności, niepewność, lękliwość ujawniają dzieci chore na przewlekłą reumatyczną chorobę serca (Kujawska 1981). 
Badania prowadzone przez Władysławę Pilecką (1990) wśród dzieci z astmą, mukowiscydozą i dzieci zdrowych pokazały, że dolegliwości somatyczne przyczyniają się do rozwoju samopoznania. Samoopisy osób z chorobą są bardziej zróżnicowane niż osób zdrowych. Dzieci z astmą dokonują autorefleksji, autoanalizy i szczerej autoprezentacji. Interesujący wydaje się fakt, że w wypowiedziach zarówno dzieci $\mathrm{z}$ chorobą, jak i zdrowe opisują siebie w podobny sposób, podając posiadanie takich cech jak: koleżeńskość, sprawiedliwość, obowiązkowość, oszczędność. Wśród cech różnicujących badane grupy wymieniane są te, które mają związek ze zdrowiem, siłą fizyczną, pracowitością i zdyscyplinowaniem. Samoocena (realna i idealna) maleje wraz z wiekiem. Dzieci z chorobą ujawniają mniejsze zadowolenie z siebie niż ich zdrowi rówieśnicy. W starszych grupach wskaźnik samoakceptacji obniża się więc, co może świadczyć o utracie wiary we własne możliwości oraz o świadomości własnych ograniczeń.

Młodzież ze schyłkową wydolnością nerek i dializowana oraz młodzież zdrowa opisuje strukturę i treść koncepcji samych siebie w różny sposób. Młodzież z chorobą ujawnia istotnie niższe poczucie własnej wartości niż zdrowa, negatywnie postrzega siebie i swoje zachowanie, znacznie wyżej pozycjonuje Ja rodzinne, które daje jej poczucie bezpieczeństwa, wsparcia i jest źródłem siły psychicznej w dawaniu sobie rady w sytuacjach zagrożenia, bólu i cierpienia (Berger 2000, za: Pilecka 2002).

Dzieci z chorobą nowotworową ujawniają w badaniach prowadzonych przez Beatę Antoszewską (2006, s. 145 i dalsze) zróżnicowany obraz siebie. Z analizy wynika, że ich samoakceptacja zależy od płci, rodzaju i rokowania choroby. Najczęściej akceptują siebie w umiarkowanym stopniu. Świadczy to o umiarkowanym zadowoleniu z siebie, co wskazuje, że mimo choroby i wynikających z niej ograniczeń zachowały wiarę we własne możliwości. Potrafią dostrzegać pozytywne aspekty swojej osoby, choć niekiedy obserwuje się u nich niższą ocenę sprawnego funkcjonowania, jak też przypisywanie sobie takiej cechy jak nerwowość (tamże, s. 232).

Niektórzy autorzy twierdzą, że obraz siebie u młodzieży z cukrzycą insulinozależną załamuje się na skutek mniejszego stopnia akceptacji własnej osoby, braku wiary w realizację swoich zamierzeń, mniejszego poczucia pewności siebie. Pomimo tego podkreśla się występujące u nich wysokie poczucie odpowiedzialności w stosunku do siebie i innych, gotowość do udzielania pomocy, podporządkowania swoich potrzeb oczekiwaniom innych oraz obrony prawa do sfery intymnej (Bartnik i in. 1994; Maciarz 1998, 2006; Prochow, Kulczycka 1967).

W samoopisie dokonywanym na skali dzieci z chorobą reumatyczną w wieku 8-16 lat wyróżniały cechy cenione z punktu widzenia społecznego, które zostały podzielone na negatywne i pozytywne. Opierając się na wartościach, jakie nadały poszczególnym cechom, można przypuszczać, że ważna jest dla nich akceptacja społeczna. Dzieci opisują siebie jako osoby lubiane, życzliwe, koleżeńskie, pomocne i uczciwe. Zwłaszcza te $\mathrm{z}$ grupy najstarszej (14-16 lat) oceniają siebie pod tym względem bardzo pozytywnie. Dzieci z grupy średniej (10-13 lat) są nieco bardziej krytyczne. Pozytywnie opisują siebie pod względem uczciwości. Większość uważa 
się za osoby mądre i ładne. Jednak cecha ładny/ładna, pomimo pozytywnej oceny, dostała u dzieci dość niską liczbę punktów. Uważają one także, że nie są postrzegane jako bardzo lubiane (dzieci z grupy najstarszej opisały siebie jako bardzo lubiane). Ambiwalentne opisy odnoszą się również do oceny pracowitości i zaradności, zwłaszcza dotyczy to dzieci z grupy średniej. Samoopis badanych jest zbudowany z cech pozytywnych. Wśród cech ocenionych przez nich wysoko znajdują się: uczciwość, bycie pomocnym, zaradność (dzieci z grupy najmłodszej i najstarszej). Dzieci z grupy najmłodszej (8-9 lat) cenią w sobie mądrość, uczciwość i koleżeńskość. Warto zwrócić uwagę na to, że 14-, 15- i 16-latki prezentują najbardziej pozytywny samoopis i to właśnie one prawie wcale nie dostrzegają u siebie cech negatywnych, oprócz braku pracowitości i mądrości (Konieczna 2012).

\section{Zakończenie}

Autopercepcja zajmuje wyjątkowe miejsce w życiu i rozwoju dzieci z chorobą przewlekłą, wpływając na subiektywną ocenę własnych możliwości oraz dostrzeganie dostępnych zasobów, ułatwiających radzenie sobie z ciągle narastającymi wymaganiami, utrudniającymi funkcjonowanie z chorobą $\mathrm{w}$ przestrzeni indywidualnej i społecznej.

Powyższe rozważania pozwalają spojrzeć na chorobę przewlekłą dziecka jak na zjawisko przebiegające w sferze fizycznej, psychicznej i społecznej. Dziecko takie egzystuje w różnych obszarach przestrzeni życiowej, o skomplikowanej niekiedy naturze kontekstu ludzkiego, napotykając tym samym trudności i ograniczenia. Mogą one mieć charakter obiektywny i subiektywny. Ograniczenia analizowane w sposób obiektywny zazwyczaj należy sprowadzać do trudnej sytuacji i doświadczanego wsparcia, w subiektywny zaś do postrzegania przez dziecko własnego życia z chorobą i stosowania przez nie strategii dawania sobie rady. Decyduje to w konsekwencji o sposobie doświadczania świata, współokreślaniu zakresu i treści spostrzegania; pomaga dziecku zrozumieć otaczający go świat, przypisywać wartość podejmowanym działaniom i określać ich charakter (por m.in. Maciarz 1998, 2006; Pilecka 2002; Ziółkowska 2010).

O stosowanych strategiach dawania sobie rady w zakresie doświadczanych dolegliwościach somatycznych i ich psychospołecznych konsekwencji w dużym stopniu decydują konstrukcje poznawcze: koncepcja siebie, koncepcja świata oraz własnej choroby (por. m.in.: Antoszewska 2006; Byra 2012; Heszen, Sęk 2007; Pasikowski 2000; Pilecka 2011; Ziarko 2014). Dlatego niezwykle ważne jest, aby je rozwijać jako osobiste zasoby dziecka, ułatwiając mu tym samym adaptację w różnych obszarach życia z chorobą.

Dokonując próby prezentacji uogólnionych rezultatów badań na temat autopercepcji dziecka z chorobą przewlekłą, nie można zapomnieć o tym, że proces poznawania przez nie samego siebie jest dynamiczny (okres rozwojowy), złożony, długotrwały i zależy od wielu czynników. Zdobywana na swój temat wiedza jest 
kodowana i transformowana do różnych form. Może mieć charakter samoświadomości indywidualnej, co w sposób bezpośredni odnosi się do treści o charakterze subiektywnym, emocjonalnym, egocentrycznym, jak i samoświadomości zewnętrznej, w której treści przede wszystkim posiadają znaczenie obiektywne, opisowe i społeczne (Gałuszka 2005; Kirenko, Byra 2011; Pilecka 2011).

Na podstawie przytoczonych wyników badań można sądzić, że dzieci i młodzież z chorobą przewlekłą ujawniają inne cechy w kształtowaniu koncepcji samych siebie niż ich zdrowi rówieśnicy. Posiadają poczucie odmienności fizycznej, a niekiedy też zaniżoną samoocenę. Niewykluczone, że u dzieci, u których choroba bardzo dynamicznie zmienia się w czasie, proces tworzenia obrazu własnej osoby jest zmienny i niestabilny. Ma to także związek z momentami nasilenia się choroby oraz jej konsekwencjami, które są dziecku nieznane, co w efekcie utrudnia proces scalania obrazu samego siebie, stanowiąc nieustanne niebezpieczeństwo dla kształtowania adekwatnej samooceny.

Przedstawione ustalenia empiryczne wskazują na potrzebę podejmowania efektywnych działań interwencyjnych i terapeutycznych, które odnosiłyby się do możliwie realnych metod opieki i wsparcia. Przy czym na szczególne podkreślenie zasługuje fakt, że nie jest możliwe wyprowadzenie uogólnionej teorii na temat wspólnej koncepcji autopercepcji u osób z chorobą przewlekłą, niezależnie od rodzaju i poziomu przewlekłej choroby, wieku, płci czy uwarunkowań społeczno-kulturowych, w których one żyją, w szczególności u dzieci. Podejmowane zabiegi rehabilitacyjne ze strony osób znaczących dla dziecka powinny być przede wszystkim ukierunkowane na niwelowanie napięcia powstałego w wyniku deprywacji potrzeb dotyczących poczucia tożsamości i własnej wartości. Zachęcanie dzieci do aktywnego uczestnictwa w „normalnym” życiu, pomoc w rozwijaniu umiejętności radzenia sobie w sytuacjach trudnych oraz korzystanie ze społecznego wsparcia przyczyniają się do ugruntowania elementów struktury własnego Ja w zakresie postrzegania siebie jako osoby z chorobą, a nie osoby chorej, oraz akceptacji własnego życia z chorobą.

\section{Bibliografia}

Adamska H. (1981). Odrębność psychologiczna dzieci chorych na reumatoidalne zapalenie stawów. W: Gałkowski T. (red.). Zaburzenia osobowości dzieci i młodzieży. Warszawa: PTWK.

Antoszewska B. (2006). Dziecko z choroba nowotworowa - problemy psychopedagogiczne. Kraków: Oficyna Wydawnicza Impuls.

Bartnik M., Brodziak A., Kołosza Z., Banasik R. (1994). Struktura osobowości młodych ludzi chorych na cukrzycę insulinozależna. Związek ze sposobem leczenia i jego skutecznościa. „Pediatria Polska”, nr 8, s. 601-608.

Bem D. (1972). Self-perception theory. W: Berkowitz L. (red.). Advances in experimental social psychology. New York: Academic Press. 
Byra S. (2012). Przystosowanie do życia z niepełnosprawnością ruchowa i choroba przewlekła. Struktura i uwarunkowania. Lublin: Wydawnictwo UMCS.

Galas B., Lewowicki T. (1991). Osobowość a aspiracje. Warszawa: Wydawnictwo Uniwersytetu Warszawskiego.

Gałuszka A. (2005). Człowiek przewlekle chory. Aspekty psychoegzystencjalne. Katowice: Wydawnictwo Uniwersytetu Śląskiego.

Harter S. (1986). Processes underlying the construction, maintenance, and enhancement of the self-concept in children. W: Suls L., Greenwald A.G. (red.). Psychological perspectives on the self. New York: Erlbaum, Hillsdale.

Heszen I., Sęk I. (2007). Psychologia zdrowia. Warszawa: PWN.

Jarymowicz M. (1985). Spostrzeganie samego siebie: porównanie „ja - inni”. W: Lewicka M. (red.). Psychologia spostrzegania społecznego. Warszawa: Książka i Wiedza.

John-Borys M. (1994). Dorastajacy w relacjach ze światem. Katowice: Wydawnictwo Uniwersytetu Śląskiego.

Joniec-Bubula K. (2004). Obraz świata w procesie tworzenia się tożsamości: światopogląd i ideologia. W: Gałgowa A. (red.). Tożsamość człowieka. Kraków: Wydawnictwo Uniwersytetu Jagiellońskiego.

Kirenko J. (2007). Indywidualna i społeczna percepcja niepełnosprawności. Lublin: Wydawnictwo UMCS.

Kirenko J., Byra S. (2011). Zasoby osobiste w chorobach psychosomatycznych. Lublin: Wydawnictwo UMCS.

Konieczna I. (2013). Budowanie poczucia koherencji u dzieci z chorobą reumatyczną. Warszawa: Wydawnictwo APS.

Konieczna I. (2012). Subiektywna ocena jakości życia przez dzieci z choroba reumatyczna. Niepublikowana praca doktorska napisana pod kierunkiem dr hab., prof. APS W. Hajnicz.

Kozielecki J. (1986). Psychologiczna teoria samowiedzy. Warszawa: PWN.

Kujawska K. (1981). Niektóre cechy osobowości dzieci z nabytymi wadami serca. W: Gałkowski T. (red.). Zaburzenia osobowości dzieci i młodzieży. Warszawa: PTWK.

Lohaus A. (1990). Gesundheit und Krankheit aus der Sicht von Kindern. Gottingen: C.J. Hogrefe.

Maciarz A. (2006). Dziecko przewlekle chore. Opieka i wsparcie. Kraków: Wydawnictwo Akademickie Żak.

Maciarz A. (1998). Psychoemocjonalne i wychowawcze problemy dzieci przewlekle chorych. Kraków: Oficyna Wydawnicza Impuls.

Majewicz P. (2002). Obraz samego siebie a zachowania młodzieży niepełnosprawnej ruchowo. Kraków: Wydawnictwo Naukowe Akademii Pedagogicznej.

Markus H. (1977). Self-schemata and processing information about the self. „Journal of Personality and Social Psychology", 35 (2), s. 63-78. 
Mazurowa M., Dyga-Konarska M., Jędrzejowska A., Kluczyńska B., Taraszewska M. (1981). Czynniki determinujące rozwój osobowości pacjentów z niedoborem wzrostu. W: Gałkowski T. (red.). Zaburzenia osobowości dzieci i młodzieży. Warszawa: PTWK.

Mądrzycki T. (2002). Osobowość jako system tworzacy i realizujący plany. Gdańsk: Wydawnictwo Uniwersytetu Gdańskiego.

Nęcka E., Orzechowski J., Szymura B. (2006). Psychologia poznawcza. Warszawa: PWN.

Niebrzydowski L. (1976). O poznawaniu i ocenie samego siebie. Warszawa: Nasza Księgarnia.

Ostafińska-Molik B. (2014). Postrzeganie siebie i własnego zachowania $w$ kontekście zaburzeń adaptacyjnych młodzieży. Kraków: Wydawnictwo Uniwersytetu Jagiellońskiego.

Pasikowski T. (200o). Stres i zdrowie. Poznań: Wydawnictwo Fundacji Humaniora.

Pilecka W. (2002). Przewlekła choroba somatyczna w życiu i rozwoju dziecka. Kraków: Wydawnictwo Uniwersytetu Jagiellońskiego.

Pilecka W. (red.). (2011). Psychologia zdrowia dzieci i młodzieży. Perspektywa kliniczna. Kraków: Wydawnictwo Uniwersytetu Jagiellońskiego.

Prochow M., Kulczycka H. (1967). Reakcje psychiczne dziecka chorego na cukrzyce. „Zdrowie Psychiczne”, nr 1, s. 73-79.

Radecka G., Sroka I., Jabłońska-Brudło J. (1998). Niektóre elementy jakości życia w okresie dorastania dziewcząt $z$ idiopatycznym bocznym skrzywieniem kregostupa leczonych gorsetem Cheneau. „Postępy Rehabilitacji”, nr 2, s. 91-98.

Rotter J.B. (1966). Generalized expectancies for internal versus external control of reinforcement. „Psychological Monographs: General and Applied”, nr 8o (1), s. 1-28.

Sufczyńska-Kotowska M., Rondio H., Chmielewska-Senko B., Rudzińska K. (1981). Warunki kształtowania osobowości młodocianych pacjentów $z$ choroba wrzodowa dwunastnicy. W: Gałkowski T. (red.). Zaburzenia osobowości dzieci i młodzieży. Warszawa: PTWK.

Vasta R., Haith M.M., Miller S.A. (1999). Child psychology: the modern science. New York: John Wiley \& Sons.

Zaborowski Z. 1998). Świadomość i samoświadomość człowieka. Warszawa: Wydawnictwo Psychologii i Kultury Eneteia.

Ziarko M. (2014). Zmaganie sięze stresem choroby przewlekłej. Poznań: Wydawnictwo Uniwersytetu Adama Mickiewicza.

Ziółkowska B. (2010). Dziecko chore $w$ domu, w szkole i u lekarza. Jak wspomagać rozwój dzieci przewlekle chorych. Gdańsk: GWP. 


\title{
SELF-PERCEPTION OF CHILDREN WITH CHRONIC DISEASE
}

\begin{abstract}
This paper attempts to synthesize the theoretical knowledge and generalize the empirical results regarding self-perception in children with chronic disease. It should be emphasized that the process of self-perception and own possibilities and restrictions in different areas of life is very complicated, long lasting and multifactorial, especially in children, taking into consideration the characteristics of particular disease entities.
\end{abstract}

Key words: self-perception, chronic disease, child with chronic disease

Iwona Konieczna - doktor, pedagog specjalny, logopeda, adiunkt na Wydziale Nauk Pedagogicznych w Instytucie Pedagogiki Specjalnej Akademii Pedagogiki Specjalnej im. Marii Grzegorzewskiej w Warszawie, członek Polskiego Towarzystwa Pedagogów Specjalnych. Główne obszary zainteresowań naukowych: edukacja i terapia dzieci ze specjalnymi potrzebami edukacyjnymi, sytuacja osób z chorobą przewlekłą i z niepełnosprawnością ruchową oraz ich rodzin w różnych obszarach życia. Autorka wielu prac z zakresu pedagogiki specjalnej, w szczególności z zakresu pedagogiki terapeutyczno-leczniczej. Adres do korespondencji: Akademia Pedagogiki Specjalnej, ul. Szczęśliwicka 40, 02-353 Warszawa. Adres e-mail: ikonieczna@aps.edu.pl. 